\title{
MENINGKATKAN MINAT BELAJAR ANAK BERKEBUTUHAN KHUSUS DI KELAS REGULER MELALUI MODEL PULL OUT DI SD N GIWANGAN YOGYAKARTA
}

\author{
INCREASING INTEREST IN LEARNING CHILDREN WITH SPECIAL \\ NEEDS MODEL THROUGH REGULAR CLASS PULL OUT \\ STATE ELEMENTARY SCHOOL OF GIWANGAN YOGYAKARTA
}

\author{
Siyam Mardini \\ Sekolah Dasar Negeri Giwangan \\ Email: siyammardini@yahoo.com
}

\begin{abstract}
Abstrak : $\quad$ SD N Giwangan sebagai sekolah penyelenggara pendidikan inklusi dalam pengelolaan kelas belum mengakomodasi siswa $\mathrm{ABK}$ secara maksimal. Hal ini menyebabkan minat belajar siswa ABK di SD N Giwangan masih sangat rendah. Siswa ABK belum mendapatkan proses pembelajaran sesuai dengan kemampuannya. Hal demikian sangat menyulitkan siswa ABK dalam mengikuti proses pembelajaran di SD N Giwangan. Proses pembelajaran mengintegrasikan siswa reguler dengan siswa ABK. Kesulitan yang dihadapi oleh siswa ABK segera dicari solusinya melalui pengelolaan proses pembelajaran di semua kelas. Penerapan model Pull Out menjadi solusi. Cara penerapan model Pull Out yaitu siswa ABK dibawa belajar di kelas inklusi untuk memahamkan pengetahuan, ketrampilan, dan psikomotornya. Penelitian ini menggunakan metode kuantitatif yaitu mendeskripsikan minat belajar siswa ABK dengan menggunakan model Pull Out. Data diperoleh melalui metode observasi, wawancara, dan dokumen. Penelitian melalui 4 tahap yaitu : (1) perencanaan (planning),(2) tindakan (acting), (3) pengamatan (observing), dan (4) refleksi (reflekting). Subyek penelitian adalah 12 guru kelas dan 26 siswa ABK. Hasil penelitian menunjukkan bahwa penggunaan model Pull Out dapat meningkatkan minat belajar siswa, hal ini dibuktikan dengan data yang diperoleh yaitu ada peningkatan yang signifikan pada kemampuan kognitif, ketrampilan, dan psikomotor siswa ABK. Berdasarkan data yang diperoleh disimpulkan bahwa model Pull Out mampu meningkatkan minat belajar siswa ABK karena kriteria keberhasilan sudah mencapai di atas 76\%.
\end{abstract}

Kata Kunci : Minat belajar, Anak Berkebutuhan Khusus, Kelas Reguler, dan model Pull Out.

Abstract : The State Elementery School Of Giwangan as school education providers inclusion in classroom management is not optimally accommodate students ABK. This causes the students' interest in The State Elementery School Of Giwangan crew is still very low. Students ABK has not received the learning process according to their abilities. It is thus very difficult for the students to follow the crew in the learning process in The State Elementery School Of Giwangan. The learning process integrates the regular students with student crew. Difficulties faced by students ABK immediately sought a solution by managing the learning process in all classes. The application of the model Pull Out a solution. How to Pull Out the implementation of a model that brought crews students learn in class to hang inclusion of knowledge, skills, and psikomotornya. This study uses quantitative methods that describe student interest ABK using models Pull Out. Data obtained through observation, interviews, and documents. Research through four stages: (1) planning (planning), (2) the action (acting), (3) observation (observing), and (4) reflection (reflekting). Subjects were 12 classroom teachers and 26 students ABK. The results showed that the use of models Pull Out can increase student interest, this is evidenced by the data obtained is no significant improvement in cognitive abilities, skills, and psychomotor student crew. Based on data obtained Pull Out conclude that the model is able to increase student interest ABK because of the success criteria has reached over $76 \%$.

Keywords: Interest in learning, Children with Special Needs, Class Regular, and models Pull Out. 



\section{PENDAHULUAN}

SD N Giwangan sebagai sekolah penyelenggara pendidikan inklusi (SPPI) mempunyai perbedaan dengan sekolah lain yang bukan penyelenggara pendidikan inklusi. Proses pembelajaran untuk Anak Berkebutuhan Khusus (ABK) di SD N Giwangan selama ini masih bersifat konvensional. Guru mengajar hanya rutinitas, hal ini menyebabkan minat belajar siswa ABK rendah. Pengelolaan kelas belum mengakomodir kemampuan siswa ABK. Model pembelajaran yang biasa dilaksanakan secara klasikal, sehingga layanan untuk siswa penyandang ABK belum maksimal. Guru Pendamping Khusus (GPK) jumlahnya hanya tiga sehingga pelayanan untuk siswa $A B K$ yang berjumlah 26 siswa tersebar di kelas 1- 6 belum maksimal. Guru pendamping mempunyai tugas membantu dan mendampingi siswa penyandang ABK. Tetapi kondisi yang sebenarnya jumlah guru pendamping khusus belum seimbang dengan jumlah siswa ABK, sehingga masih sangat kurang. Pada saat proses pembelajaran, GPK tidak bisa setiap saat melakukan pendampingan di kelas secara bergantian.

Di SD N Giwangan terdapat guru pendamping yang membantu dan mendampingi siswa penyandang ABK tetapi kondisi guru pendamping khusus tersebut jumlahnya belum seimbang dengan jumlah siswa $\mathrm{ABK}$, sehingga masih sangat kurang. Kondisi ini tidak proporsional karena mestinya siswa penyandang ABK akan lebih maksimal jika model layanan 1:1 yaitu satu siswa ABK dapat dilayani oleh satu GPK. Melihat kondisi nyata yang ada dan sebenarnya, hal tersebut menyebabkan guru kelas mengalami kesulitan dalam mengelola kelas dengan baik dan maksimal. Proses pembelajaran siswa $\mathrm{ABK}$ menjadi satu di dalam kelas reguler dengan pengaturan tempat duduk disesuaikan kebutuhan siswa ABK.

Siswa ABK dianggap mempunyai daya tangkap kognitif sama dengan siswa reguler. Keterbatasan GPK di SD N Giwangan menuntut guru kelas harus mampu menjadi pendamping siswa ABK dalam belajar. Rencana pelaksanaan pembelajaran (RPP) yang digunakan belum disesuaikan dengan kondisi siswa ABK. Proses pembelajaran terintegrasi artinya siswa ABK belajar bersama dengan siswa reguler, hal ini tentunya sulit bagi siswa ABK jika yang dituntut aspek pengetahuan. Sehingga guru perlu mengembangkan aspek psikomotor dan ketrampilan.

Proses pembelajaran siswa $\mathrm{ABK}$ yang dilaksanakan di kelas reguler membutuhkan pendampingan yang berbeda. Proses pembelajaran supaya lebih maksimal memerlukan strategi yang berbeda dengan siswa reguler. Pembelajaran model Pull Out diharapkan bisa menjembatani siswa $\mathrm{ABK}$ dapat belajar secara klasikal dan belajar di kelas inklusi. Guru kelas pun harus esktra dalam memahamkan materi kepada siswa. Sehingga diperlukan perbaikan dan modifikasi dalam pembelajaran kepada siswa ABK dan juga siswa reguler. Kondisi ini menjadi perhatian karena pembelajaran secara klasikal perlu dimodifikasi dengan model lain. Di sini peran GPK sangat penting karena GPK menjadi mitra guru kelas dalam mengelola proses pembelajaran yang baik untuk siswa reguler dan siswa ABK. Siswa ABK membutuhkan model pembelajaran model Pull Out dengan maksud untuk lebih bisa mengekspresikan diri secara maksimal tanpa malu dengan siswa lainnya.

Rumusan masalah dalam penelitian ini yaitu: Bagaimana meningkatkan minat belajar Anak Berkebutuhan Khusus di kelas reguler melalui model Pull Out di SD N Giwangan, Yogyakarta? Maka tujuan penelitian dilakukan yaitu : Meningkatkan minat belajar Anak Berkebutuhan Khusus di kelas reguler melalui model Pull Out di SD N Giwangan, Yogyakarta. Manfaat penelitian ini adalah SD N Giwangan sebagai sekolah inklusi mampu memberikan layanan yang maksimal kepada siswa $\mathrm{ABK}$ dan siswa reguler dalam belajar sehingga sekolah mampu memfasilitasi semua siswa dan tidak ada diskriminasi.

Proses pembelajaran di sekolah inklusi berbeda dengan proses pembelajaran di sekolah lainnya. Perbedaan tersebut sangat nyata dalam memberikan layanan kepada siswa ABK. Model pengelolaan siswa $\mathrm{ABK}$ di kelas reguler dapat berlangsung bersamaan dalam satu kelas atau dapat juga dipisah. Model pemisahan siswa $\mathrm{ABK}$ dari kelas reguler pada saat-saat tertentu memang dibutuhkan dan sangat mendukung minat belajar siswa ABK.

Model Pull Out bisa dilaksanakan pada saat tertentu dengan waktu insedentil atau bisa juga dibuat jadwal. Siswa ABK yang berada di kelas tetap mengikuti proses pembelajaran 
seperti siswa reguler lainnya tanpa ada perbedaan. Pada saat siswa ABK mengalami kesulitan dan perlu pendampingan oleh guru GPK atau guru kelas pada waktu yang bersamaan atau berbeda dapat dilaksanakan di ruang kelas khusus yaitu kelas inklusi.

Belajar merupakan proses panjang dan terus-menerus dilakukan oleh manusia untuk berubah ke arah yang lebih baik. Hasil belajar juga perlu waktu karena antara siswa yang satu dengan siswa lain berbeda, ada yang membutuhkan waktu pendek dan ada yang membutuhkan waktu panjang. Proses pemahaman yang membutuhkan waktu agak lama ini membuat siswa jenuh. Kejenuhan menjadi pendorong siswa malas sehingga menurunkan daya pikir dan minat siswa.

Adanya kemauan pada siswa untuk melakukan sesuatu itulah yang melatarbelakangi munculnya minat. Bagi sebagian anak-anak tertentu rasa bosan muncul karena tidak tertarik melakukan sesuatu. Ketidaktertarikan pada sesuatu tersebut memunculkan rendahnya minat untuk belajar. Ketidaktertarikan tersebut memunculkan rendahnya minat untuk belajar. Dalam proses belajar, seorang guru harus mempunyai kemampuan untuk membangkitkan minat siswa untuk belajar. Belajar merupakan kebutuhan manusia dan tidak bisa terlepaskan dari hidup sehari-hari. Siswa belajar karena didorong oleh kekuatan mentalnya (Dimyati, 1994: 80).

Kekuatan mental mempunyai peran penting dan utama untuk membangkitkan minat belajar pada siswa. Kemauan yang mendalam telah menimbulkan minat yang besar untuk belajar. Melalui belajar akan diperoleh berbagai kecakapan, ketrampilan, dan sikap (Margaret E, 1994: 1).

Menurut kamus umum Bahasa Indonesia kata minat berarti kesukaan (kecenderungan hati) kepada sesuatu. Hal ini berarti kesukaaan siswa pada sesuatu harus dikondisikan sehingga siswa ada kecenderungan senang melakukan dan minat belajar yang tinggi akan membawa perubahan pada psikomotorik, ketrampilan dan kognisi siswa.

Banyak kecakapan yang diperoleh dalam belajar, sebagai contoh siswa yang belajar menyelesaikan masalah jika kelak menemukan masalah akan mampu mengatasi masalah tersebut dengan cepat. Sikap yang dapat dikembangkan dalam belajar yaitu pantang menyerah dengan segala resiko yang dihadapi. Ketrampilan menyelesaikan masalah dan berani menghadapi segala resiko menjadi tujuan perubahan dalam belajar. Karena dengan demikian, ada perubahan perilaku pada siswa. Minat belajar yang tinggi akan membawa perubahan pada sikap, ketrampilan dan kognisi siswa. Setiap saat guru harus mampu menggugah minat siswa untuk belajar. Dalam belajar guru dapat menerapkan unsur nilai-nilai yang berkembang di masyarakat. Belajar juga mengembangkan nilai-nilai positif yang berlaku di masyarakat.

Di sekolah penyelenggara pendidikan inklusi istilah anak berkebutuhan khusus (ABK) bukan hal yang aneh. Istilah ABK justru menjadi pendorong bagi sekolah untuk melakukan perbaikan-perbaikan dalam pembelajaran maupun mutu pendidikan. Bagi sebagian orang ABK dipandang sebelah mata bahkan menjustifikasi dengan kecacatan.

Tuhan menciptakan manusia dengan berbagai kharakteristiknya. Tuhan juga menciptakan manusia berbeda-beda, artinya bahwa seorang anak lahir di dunia tidak ada yang sama. Tetapi kelahiran anak di dunia terkadang tidak seperti yang diharapkan orang tuanya, mungkin anak lahir mengalami kecacatan. Kecacatan yang dimiliki ini yang menyebabkan ada sesuatu yang kurang. Tidak ada satu anak manusia tidak memiliki kekurangan (Rusli Ibrahim,2011:8).

Pada dasarnya manusia ingin lahir sempurna dan tidak mengalami kekurangan atau cacat baik fisik maupun mentalnya. ABK berarti anak dengan kharakteristik khusus yang berbeda dengan anak pada umumnya tanpa selalu menunjukkan pada ketidakmampuan mental,emosi atau fisik. Yang termasuk anak ke dalam ABK antara lain: tunanetra, tunarungu, tunagrahita, tunadaksa, tunalaras, kesulitan belajar, gangguan perilaku, anak berbakat, dan anak dengan gangguan kesehatan (Mudjito A.K., $2012: 25)$.

Kharakteristik ABK yang mengalami ketidakmampuan mental, emosi atau fisik bukan menjadi hambatan untuk memperoleh pendidikan. Siswa ABK yang mengalami ketidakmampuan memerlukan layanan yang berbeda pula dengan siswa pada umumnya. Hal ini sangat dimaklumi karena kondisi siswa juga 
berbeda, sehingga perilaku atau cara belajarnya juga berbeda. ABK juga sering disebut dengan istilah anak luar biasa.

Istilah lain yang sering diucapkan orang yaitu anak berkelainan. Anak dengan kelainan fisik diklasifikasikan dalam kelompok seperti cerebral palsy, spina bifida, dan muscular dystrophy. Yang termasuk anak berkelainan adalah adanya hendaya tidak hanya secara fisik dan sensoris, tetapi batasan perilaku anak apabila mempunyai keterbelakangan mental, gangguan emosi, ataupun penyimpangan perilaku (Bandi Delphie, 2009 : 114).

Bandi Delphie mengungkapkan dalam bukunya Psikologi Perkembangan bahwa anak berkebutuhan khusus adalah sebutan lain untuk anak cacat atau luar biasa. Anak berkebutuhan khusus yang dimaksud yaitu: tunanetra, tunarungu dan tunawicara, tunadaksa, kesulitan perkembangan fungsional, tunalaras, tunaganda, kesulitan belajar, hiperaktif, autistik, dan berbakat.

Pendidikan khusus merupakan pendidikan bagi siswa yang memiliki tingkat kesulitan dalam mengikuti proses pembelajaran karena kelainan fisik, emosional, mental, sosial, dan atau memeliki potensi kecerdasan dan bakat istimewa. Siswa ABK yang mengikuti pendidikan di sekolah inklusi dapat ditangani dengan baik. Di sekolah penyelenggara pendidikan inklusi melaksanakan identifikasi terhadap siswa yang dicurigai ABK. Siswa yang dicurigai sebagai ABK kemudian dilakukan assesmen. Dalam melakukan assesmen sekolah bekerja sama dengan instansi terkait dan psikolog.

Proses pembelajaran integrasi di sekolah inklusi membaurkan siswa ABK dengan siswa normal. Proses pembelajaran dapat dikaitkan dengan pengalaman belajar siswa. Karena hambatan yang ada dalam diri siswa ABK, maka siswa ABK pada umumnya tidak bisa mengikuti proses pembelajaran yang dirancang untuk siswa-siswa pada umumnya/reguler (Modul Pelatihan Pendidikan Inklusif, 2009: 93).

Lingkungan belajar perlu diciptakan supaya kondusif dan ramah terhadap siswa ABK. Lingkungan kelas reguler sangat dibutuhkan oleh siswa ABK, karena siswa ABK dapat belajar di manapun tanpa dibedakan. Siswa ABK dapat memanfaatkan fasilitas belajar di kelas reguler pada umumnya maupun di kelas terpisah. Proses pembelajaran inklusif di kelas yang melibatkan siswa ABK dan siswa yang tidak mempunyai kelainan membutuhkan pengelolaan yang baik.

SD N Giwangan sebagai sekolah penyelenggara pendidikan inklusif, sekolah mempunyai kewajiban menampung semua siswa. Kondisi siswa di sekolah heterogen karena siswa terdiri atas siswa reguler dan siswa ABK. Walaupun SD N Giwangan merupakan sekolah inklusif semua siswa ABK mendapatkan layanan yang berbeda sesuai kemampuan dan kebutuhan siswa. Pendidikan inklusif adalah penempatan siswa ABK tingkat ringan, sedang, dan berat secara penuh di kelas reguler (Direktorat Pembinaan Pendidikan Khusus dan Layanan Khusus, 2013:4).

Kebutuhan akan pendidikan memerlukan penanganan yang berbeda. Perbedaan ABK perlu mendapat layanan khusus. Alternatif pendidikan layanan khusus, maksudnya menjamin siswa memperoleh layanan pendidikan secara pasti, dengan kualitas yang lebih baik dibandingkan dengan tanpa dilakukan layanan khusus (Mudjito A.K., 2012 : 108).

Kurikulum untuk siswa ABK menggunakan kurikulum modifikasi (penyelarasan). Kurikulum modifikasi digunakan sedemikian rupa sehingga sesuai dengan kebutuhan siswa (Direktorat Pembinaan Pendidikan Khusus dan Layanan Khusus, 2013:20). Kelas reguler maksudnya kelas yang digunakan oleh siswa-siswa umum. Kelas Pull Out maksudnya kelas atau ruang terpisah dari siswa umum. Pelaksanaan model Pull Out yaitu siswa belajar di kelas reguler namun dalam waktu tertentu ditarik dari kelas reguler ke ruang sumber untuk belajar dengan guru pembimbing khusus.

Model pembelajaran dengan model Pull Out memerlukan pengelolaan yang cermat mulai dari fasilitas sarana dan prasana serta ketersediaan pendidik (guru). Sekolah melakukan pencermatanan secara mendalam sebelum penerapan model tersebut. Di kelas reguler memang belum memberi jaminan yang lebih baik dalam memberikan layanan secara personal kepada siswa ABK. Di kelas reguler siswa $\mathrm{ABK}$ dan siswa yang lain menjadi satu dalam mendapatkan ilmu.

Model pembelajaran di kelas reguler ada kelemahan, siswa ABK yang berada di dalam 
kelas mendapatkan materi yang sama sehingga mengalami kesulitan dalam menerima pelajaran. Kondisi ini diatasi dengan menerapkan model pembelajaran Pull Out. Model Pull Out dilakukan pada waktu-waktu tertentu yang memang dibutuhkan untuk memberikan pemahaman yang dibutuhkan oleh siswa ABK. Model Pull Out digunakan pada setiap siswa ABK yang membutuhkan pemahaman sesuai kemampuannnya. Model Pull Out dilakukan di kelas berbeda terpisah dengan siswa normal lainnya. Pelaksanaan pembelajaran dengan model Pull Out siswa dibawa keluar kelas dan dibawa ke kelas khusus atau kelas inklusi.

Model Pull Out membutuhkan ruang khusus, guru khusus, alat khusus, media khusus, dan waktu khusus, sehingga perlu dibuat program dan jadwal pelaksaannnya. Kondisi ini yang menyebabkan penerapan model Pull Out membutuhkan pencermatan yang mendalam. Model pembelajaran Pull Out membutuhkan pengaturan jadwal. Model Pull Out dilakukan sebagai bentuk pemberian layanan yang baik kepada siswa ABK.

Penerapan model Pull Out perlu disiapkan secara cermat. Sekolah melakukan pemetaan dan kajian terhadap kebutuhan siswa ABK. Langkah-langkah penerapan model Pull Out sebagai berikut : (1) Persiapan yaitu tahap menyediakan sarana dan prasana berupa alat, media, kelas, dan guru. (2) Pelaksanaan yaitu guru kelas melakukan komunikasi dengan GPK atau sebaliknya GPK melakukan komunikasi kepada guru kelas. Keduanya harus aktif melakukan komunikasi tentang pelaksanaan yang tepat dan memang sangat dibutuhkan oleh siswa ABK. Pelaksanaan model Pull Out di kelas khusus yang berbeda. Di kelas khusus tersebut siswa ABK akan mendapatkan pendampingan. Pelaksanaan pembelajaran dapat dilakukan secara rutin dalam pertemuan setiap minggunya. (3) Evaluasi yaitu setiap selesai pendampingan GPK melakukan evaluasi terhadap proses pendampingan yang dilakukan kepada setiap siswa ABK. Hasil evaluasi disampaikan kepada guru kelas untuk ditindak lanjuti bersama. (4) Tindak lanjut yaitu antara guru kelas dan GPK melakukan komunikasi capaian belajar siswa ABK. Hasil capaian siswa ABK menjadi catatan keduanya sebagai dasar melakukan pendampingan secara kontinyu.
Pendidikan adalah hak semua warga negara tanpa kecuali siswa ABK. SD N Giwangan sebagai penyelenggara pendidikan inklusif wajib mengelola siswa ABK. Pengelolaan siswa ABK membutuhkan program yang mampu memberikan layanan yang baik. Proses pembelajaran yang terintegrasi antara siswa ABK dengan siswa normal memerlukan kurikulum yang berbeda dengan sekolah lain.

Modifikasi kurikulum diperlukan untuk tetap memberikan layanan yang maksimal kepada siswa ABK. Bentuk layanan yang dilakukan sekolah kepada siswa $\mathrm{ABK}$ yaitu menjamin proses pembelajaran bagi siswa $\mathrm{ABK}$ dengan baik. Indikasi ketercapaian layanan di antaranya tersedianya GPK, kelas, alat, media, dan proses pembelajaran. Sekolah juga memberikan layanan berupa pendampingan secara kontinyu. Proses pembelajaran untuk siswa ABK di kelas reguler menggunakan model Pull Out. Model Pull Out dilakukan oleh guru pendamping. Pembelajaran sangat menarik dan mendorong siswa $\mathrm{ABK}$ untuk belajar lebih bersemangat serta antusias belajar karena siswa ABK dapat belajar sesuai kemampuan yang dimiliki.

Model Pull Out digunakan karena dapat memberikan layanan yang lebih baik kepada siswa ABK. Model ini digunakan setelah dilakukan pemetaan dan kajian yang mendalam. Hasil kajian diharapkan bahwa model Pull Out mampu : (1) Membantu guru dalam memahamkan materi ajar kepada siswa ABK; 2) Siswa ABK sangat senang dan antusias belajar; 3) Siswa ABK dapat belajar sesuai kemampuan yang dimiliki.

\section{METODE PENELITIAN}

Pelaksanaan penelitian sekolah ini dilaksanakan di SD N Giwangan, Jalan Tegalturi No. 45, Umbulharjo, Yogyakarta pada tahun pelajaran 2014/2015 semester 2. Penelitian ini termasuk penelitian tindakan sekolah karena memiliki beberapa karakteristik antara lain: (1) Pertama, adanya permasalahan yang dihadapi oleh kepala sekolah mengenai layanan sekolah kepada siswa $\mathrm{ABK}$ dan guru ketika proses pembelajaran di kelas reguler, siswa $A B K$ tidak bisa maksimal dalam mengikuti pelajaran bersama siswa pada umumnya. Hal ini terjadi karena siswa ABK dengan segala keterbatasannya, belum mampu menangkap 
pelajaran yang disampaikan guru. Kondisi ini menyebabkan minat belajar siswa $\mathrm{ABK}$ rendah. Sehingga perlu diberikan pendampingan tersendiri. Pendampingan untuk siswa ABK berada di kelas inklusi yang terpisah dengan siswa reguler. (2) Masih banyak siswa ABK yang tidak betah di kelas karena sulit mengikuti pelajaran.

Penelitian ini membutuhkan waktu 4 bulan yaitu penelitian dilaksanakan pada bulan Maret - Juni 2015. Rencana waktu yang digunakan dalam 4 bulan yaitu : (1) Bulan Maret 2015 mengidentifikasi masalah yang muncul, menentukan tindakan yang akan dilakukan dan menentukan instrumen yang akan digunakan. (2) Bulan April 2015 siklus I, melakukan tindakan pertama dengan melakukan pengamatan di kelas-kelas, menemukan kendala yang dihadapi siswa ABK saat di kelas-kelas, melakukan wawancara kepada guru pendamping khusus, siswa $\mathrm{ABK}$ ataupun siswa reguler, dan guru kelas, dan melakukan evaluasi dan membuat rekomendasi hasil evaluasi. (3) Bulan Mei 2015 siklus II menentukan langkah-langkah rekomendasi hasil evaluasi dan menyimpulkan hasil penelitian. (4) Bulan Juni 2015 digunakan untuk menyusun laporan.

Fokus dalam penelitian ini tentang pengelolaan dan layanan proses pembelajaran untuk siswa ABK sebanyak 26 siswa dan guru kelas sebanyak 12 guru. Prosedur penelitian yang digunakan yaitu (1) Perencanaan (planning). Pada tahap perencanaan ini ada beberapa kegiatan yang dilakukan terkait kegiatan-kegiatan yang akan dilakukan pada penelitian. Beberapa tahap yang dilakukan dalam tahap perencanaan yaitu merumuskan masalah yang akan dipecahkan, melakukan komunikasi dengan guru pendamping khusus, menentukan fokus penelitian yaitu siswa $\mathrm{ABK}$ yang berada di kelas-kelas, mendesain model pembelajaran yang akan dilakukan baik di kelas reguler maupun di kelas inklusi, menyusun jadwal kegiatan yang akan dilakukan selama proses penelitian, menyusun RPP dan bahan ajar yang akan digunakan oleh guru, dan menyusun lembar pengamatan. (2) Pelaksanaan (acting). Pada tahap pelaksanaan ini guru melakukan langkahlangkah tindakan sesuai dengan rencana awal. Pada tahap pelaksanaan semua bahan ajar, RPP, dan lembar kerja sudah siap. Proses pembelajaran dilakukan pada tahap ini dengan menggunakan RPP yang sudah disusun sebelumnya. Beberapa langkah yang ditempuh pada tahap pelaksanaan yaitu guru mengkondisikan kelas dalam pembelajaran, guru menyampaikan materi ajar sesuai RPP, guru kelas dan guru pendamping khusus melakukan pendampingan kepada siswa ABK, dan melakukan tindakan sesuai Siklus I dan Siklus II. (3) Pengamatan (observing). Melakukan pengamatan selama proses pembelajaran kepada guru dan siswa $\mathrm{ABK}$ dalam kelas reguler dan kelas inklusi. Pengamatan dilakukan mulai awal proses pembelajaran, selama proses pembelajaran dan sesudah pembelajaran. Proses pembelajaran perlu dilakukan pengamatan secara cermat dan teliti untuk mendapatkan informasi yang sebanyak-banyaknya sehingga dapat digali informasi secara mendalam. Pengamatan dilakukan dengan menggunakan lembar pengamatan yang sudah disusun.

Beberapa hal yang dijadikan pertimbangan dalam pengamatan dan dicermati sungguh-sungguh adalah keterlibatan siswa ABK dalam belajar, kemampuan siswa ABK sebelum penelitian, dan mencermati perubahan kemampuan siswa $\mathrm{ABK}$ dan guru saat mengajar. (4) Refleksi (reflecting). Pada tahap refleksi ini merupakan tahap akhir dalam penelitian tindakan sekolah (PTS). Pada tahap ini peneliti melakukan evaluasi semua kegiatan dari awal sampai akhir. Refleksi digunakan untuk mengetahui perubahan hasil belajar siswa sesuai yang diperoleh selama proses pembelajaran. Dalam refleksi ini akan diperoleh masukan tentang efektifitas tindakan yang yang sudah dilakukan dalam setiap siklus penelitian. Sehingga akan diperoleh kendala-kendala yang muncul setiap siklus. Kendala yang muncul akan dicarikan solusinya.

Pada saat refleksi akan muncul solusi untuk memperbaiki kendala yang muncul. Pada tahap ini akan terlihat apakah tindakan yang dilakukan untuk minat belajar anak berkebutuhan khusus melalui model Pull Out mengalami peningkatan. Hasil refleksi ini digunakan sebagai acuan untuk merencakan dan menentukan tindakan-tindakan pada tahap berikutnya.

Metode penelitian ini menggunakan teknik : (1) Observasi. Teknik observasi dilakukan dengan melakukan pengamatan yang cermat dari awal sampai akhir proses penelitian. 
Catatan lapangan dalam penelitian ini berupa lembar observasi, pada lembar observasi tersebut akan digunakan sebagai bahan pengamatan selama kegiatan pembelajaran di kelas-kelas dan di ruang inklusi. (2) Wawancara. Teknik wawancara digunakan untuk memperkuat pengumpulan data melalui observasi di kelaskelas selama proses kegiatan pembelajaran. Wawancara dilakukan kepada siswa, guru kelas dan GPK. Untuk melakukan wawancara perlu disusun terlebih dahulu kisi-kisi yang akan digunakan dalam wawancara. (3) Dokumen. Dokumen yang dimaksud yaitu semua dokumen otentik dari guru. Teknik analisis data dilakukan setelah semua data dalam penelitian dilakukan diperoleh. Dari data yang terkumpul dilakukan analisis tentang semua data yang sudah dihimpun untuk disimpulkan. Data-data yang terkumpul dipilah-pilah dan selanjutnya dilakukan klarifikasi pada jawaban yang akan disimpulkan. Analisis data menggunakan kriteria sebagai berikut: amat baik: 86 - 100, baik : $76-$ 85 , cukup : $61-75$, dan kurang : $\leq 60$.

Indikator keberhasilan tindakan dilakukan untuk mengetahui ada tidaknya minat belajar siswa $\mathrm{ABK}$ atau peningkatan minat belajar siswa ABK dalam penelitian dengan menggunakan model yang digunakan yaitu model Pull Out. Peningkatan minat belajar siswa ABK di kelas reguler dapat diketahui melalui tindakan yang dilakukan pada siklus I dan II. Keberhasilan penelitian ini dilakukan melalui penghitungan pada tiga kemampuan yaitu kognitif, ketrampilan, psikomotor. Keberhasilan penelitian ini didukung data sebesar minimal 76 $\%$ dan ada peningkatan pada minat belajar siswa ABK dengan model Pull Out.

\section{HASIL PENELITIAN DAN PEMBAHASAN}

\section{Hasil Penelitian}

SD N Giwangan merupakan sekolah penyelenggara pendidikan inklusi (SPPI) dengan 12 rombongan belajar. Jumlah siswa ABK pada tahun pelajaran 2014/2015 di SD N Giwangan sebanyak 26 siswa. Siswa tersebut terbagi dalam semua kelas yaitu kelas 1- 6. SD N Giwangan sebagai SPPI terutama jika ditinjau dari segi lingkungan dan sarana prasarana sudah baik. Kelas inklusi yang memang digunakan untuk memberikan layanan khusus kepada siswa ABK sudah ada, tetapi pemanfaatannya belum maksimal. GPK pun belum menyusun program yang baik untuk memanfaatkan ruang inklusi. Lingkungan sekolah yang memang sudah terkondisi menjadi sekolah inklusi mempunyai siswa sangat beragam. Siswa reguler juga mampu menempatkan dirinya membaur dengan siswa ABK.

Kondisi berbeda terjadi pada pengelolaan proses pembelajaran bagi siswa $A B K$ yang terdapat di setiap kelas. Sebanyak 26 siswa ABK mempunyai kelainan yang beragam. Pengelolaan kelas yang belum sesuai dengan standar pengelolaan sebagai SPPI perlu dilakukan pembenahan. Permasalahan yang muncul adanya proses pembelajaran di kelas reguler. Guru kelas belum secara khusus memberikan layanan yang maksimal kepada siswa ABK. Di sini terjadi permasalahan yang muncul terkait dengan rendahnya minta siswa $\mathrm{ABK}$ dalam belajar.

Kondisi ini akan semakin parah jika tidak segera dilakukan pembenahan, karena berakibat pada kondisi belajar siswa ABK. Kondisi yang nampak jelas rendahnya minat belajar bagi siswa reguler. Siswa ABK dan siswa reguler mendapat perlakuan yang sama dalam hal tuntutan kemampuan kognitifnya. Hal ini didukung dengan beberapa hal yaitu: (1) Tuntutan orang tua siswa. Kondisi nyata yang dihadapi oleh sekolah terkait dengan tuntutan orang tua siswa ABK. Sebagian besar orang tua siswa mempunyai keinginan anaknya belajar supaya cerdas. Tuntutan orang tua siswa sangat memberatkan bagi siswa $\mathrm{ABK}$. Hal ini juga dilatar belakangi karena orang tua siswa ABK tidak mau anaknya digolongkan sebagai siswa ABK. Kemauan orang tua siswa ABK yang kuat menyebabkan siswa ABK harus menguasai materi yang sama dengan siswa reguler. (2). Tuntutan sekolah. SD N Giwangan sebagai salah satu sekolah yang tergolong sekolah besar mempunyai visi mendidik siswanya unggul dalam prestasi. Hal ini dikuatkan tuntutan sekolah yang menempatkan sekolah sebagai sekolah yang mempunyai peringkat atas dalam ujian sekolah daerah. Sebagai sekolah pengelenggara pendidikan inklusi belum mampu menciptakan layanan yang baik kepada siswa ABK, bukan memenuhi target peringkat sekolah.

\section{Pembahasan}

\section{Siklus I}

Siklus I dilaksanakan melalui dua kali pertemuan, yaitu pertemuan pertama 
dilaksanakan ketika guru kelas mengajar dan pertemuan kedua ketika GPK mengajar. Pada tahap perencanaan dengan melakukan komunikasi intensif kepada 12 guru kelas dan 3 guru pendamping dan guru menyiapkan RPP yang akan digunakan dalam mengajar. Guru mengkondisikan kelas supaya semua siswa siap mengikuti proses pembelajaran. Guru mengawali pendahuluan dengan berdoa bersama yang dipimpin oleh ketua kelas. Guru juga memberikan motivasi dengan cara menanyakan siswa yang tidak hadir, menyampaikan tujuan, menanyakan pengalaman hasil belajar. Di sini terjadi komunikasi aktif antara siswa dan guru. Siswa dengan senang dan berlomba-lomba menunjukkan hasil karya kepada guru untuk ditampilkan. Guru secara khusus membantu kesulitan belajar siswa dengan disesuaikan kemampuan belajar siswa ABK. Di kelas inklusi siswa ABK dilatih tentang kemapuan kognitif, ketrampilan, dan psikomotornya.

Pada pertemuan kedua pembelajaran dilaksanakan di kelas inklusi. Guru menyusun RPP dalam 2 pertemuan. RPP untuk siswa ABK dibuat berbeda dengan siswa reguler. Perbedaannya pada penurunan indikator, materi, dan penilaiannya yaitu disesuaikan dengan kemampuan siswa ABK. Menyusun skenario proses pembelajaran dengan model Pull Out. Model pembelajaran yang digunakan untuk siswa ABK yaitu model Pull Out. Model Pull Out dilaksanakan berdasarkan jadwal yang sudah disepakati yaitu pada hari Jumat dan Sabtu. Siswa ABK pada hari tersebut dibawa ke kelas inklusi. Pada hari Senin-Kamis siswa ABK tetap mengikuti proses pembelajaran di dalam kelas reguler bersama siswa yang lain. Tetapi jika pada hari Senin dan Kamis siswa ABK ada kesulitan dan membutuhkan pendampingan dari guru pendamping tetap dapat dilaksanakan. Ruang inklusi berguna untuk memberikan bantuan kepada siswa ABK yang mengalami kesulitan dalam belajar.Model Pull Out dilaksanakan berdasarkan jadwal yang sudah disepakati yaitu pada hari Jumat dan Sabtu. Skenario model Pull Out yang akan dilakukan yaitu: 1) Guru menyiapkan dan mengkondisikan kelas, 2) Guru menempatkan siswa ABK pada posisi duduk terdepan/yang mudah dijangkau guru, 3) Siswa ABK mengikuti pelajaran di kelas reguler, 4) Guru membantu siswa $A B K$ jika ada kesulitan, 5) Guru mengidentifikasi kesulitan belajar siswa $\mathrm{ABK}$, dan 6) Guru melakukan komunikasi dengan guru pendamping.

Pendampingan proses belajar untuk siswa ABK dilakukan oleh guru selama proses pembelajaran berlangsung. Proses pembelajaran di kelas reguler dan di kelas inklusi. Ketika siswa ABK mengikuti proses pembelajaran di kelas reguler maka guru kelas wajib memberikan bantuan maksimal. Jika proses pembelajaran di kelas inklusi maka guru pendamping memberikan bantuan penuh. Bahkan pendampingan belajar bisa dilakukan di luar kelas.

Pada saat proses pembelajaran dilakukan pencermatan mendalam melalui dokumen dan instrumen pengamatan. Instrumen digunakan untuk mendapatkan data yang lebih lengkap dalam penelitian. Dokumen dan catatan lapangan digunakan untuk memperkuat data hasil pengamatan.

Pelaksanaan observasi dari 12 guru kelas, indikator pembelajaran belum diturunkan. Kemampuan kognitif siswa ABK sebesar $62 \%$, sedangkan $38 \%$ siswa mengalami kesulitan belajar. Kemampuan ketrampilan $64 \%$, sedangkan $36 \%$ perlu ditingkatkan. Kemampuan psikomotor $67 \%$, sedangkan $33 \%$ perlu ditingkatkan. Berikut ini gambaran data kemampuan siswa ABK.

\section{Data kemampuan siswa ABK Siklus I}

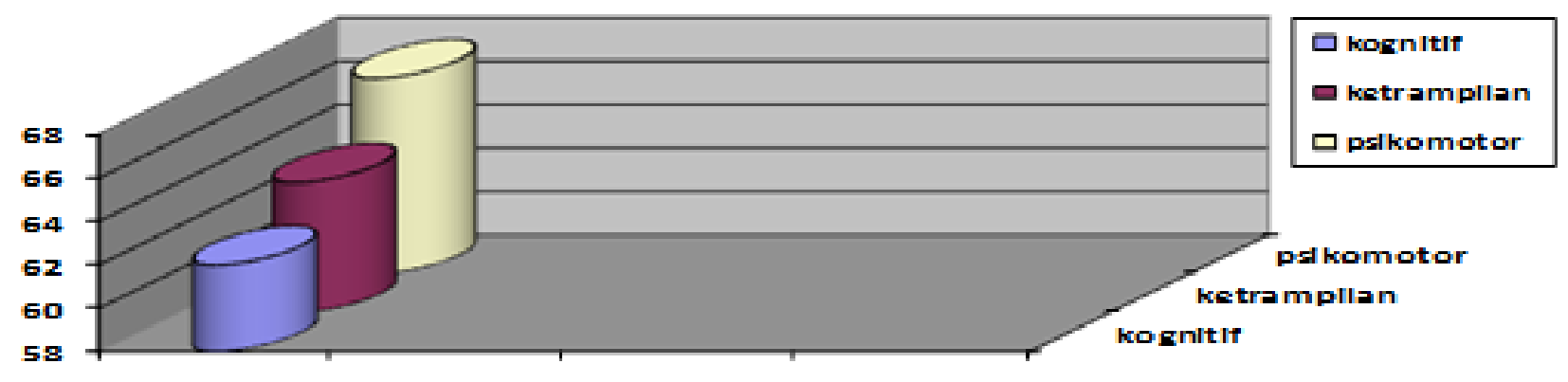


Pada diagram di atas menunjukkan bahwa kemampuan kognitif siswa ABK lebih rendah yaitu $62 \%$, kemampuan ketrampilan 64 $\%$, dan psikomotor $67 \%$. Berdasarkan data pada siklus I diperoleh data bahwa kemampuan kognitif sebesar $62 \%$, ketrampilan $64 \%$, dan psikomotor sebesar $67 \%$. Dari data yang dihimpun tersebut, hasil penelitian siklus I menunjukkan masih belum tercapai $76 \%$, ini berarti siklus I belum berhasil. Maka perlu ditetapkan langkah-langkah untuk melakukan tindak lanjut pada siklus II. Langkah-langkah kegiatan yang dilakukan pada siklus II garis besarnya yaitu : 1)Menyampaikan hasil penelitian kepada guru, 2) Menyusun RPP yang akan digunakan pada kegiatan siklus II, 3) Melakukan observasi di dalam kelas reguler dan inklusi, 4) Menganalisis hasil penelitian, dan 5) Menindaklanjuti hasil penelitian

\section{Siklus II}

Menindaklanjuti hasil penelitian pada siklus I maka perlu dilakukan tindakan nyata, sehingga membutuhkan perencanaan yang matang. Tahap perencanaan dimulai dengan menyusun RPP. Menindaklanjuti RPP yang telah dilakukan pada siklus I maka perlu ada pembenahan. RPP yang disusun benar-benar ada kegiatan yang nyata untuk siswa ABK baik untuk kegiatan pembelajaran di kelas reguler maupun di kelas inklusi. Pada RPP siklus II ini sudah dimasukkan penurunan pada indikator, materi, dan penilaian. RPP yang digunakan di kelas dikombinasi dengan kelas reguler, sedangkan pada bagian kegiatan inti ditambah kegiatan di kelas inklusi sebagai model Pull Out. Penekanan model Pull Out dibuat tersendiri bersama guru pendamping. RPP disusun dengan cermat memenuhi standar proses untu pembelajaran di kelas Pada bagian kegiatan inti ditambah kegiatan di kelas inklusi sebagai model Pull Out.

Model Pull Out dilaksanakan di semua kelas 1-6 yang terdapat siswa ABK. Melaksanakan proses pembelajaran dengan model Pull Out di kelas inklusi dengan tindakan lebih oleh guru pendamping. Guru melakukan kegiatan pembelajaran dengan model Pull Out sebagai tindak lanjut untuk memantapkan penggunaan model Pull Out. Melakukan observasi di kelas reguler dan kelas inklusi. Skenario model pembelajaran model Pull Out yang akan digunakan pada siklus II yaitu : 1)
Guru menyiapkan dan mengkondisikan kelas untuk memulai pelajaran, 2) Guru menempatkan siswa ABK pada posisi duduk terdepan/ yang mudah dijangkau guru, 3) Siswa ABK mengikuti pelajaran di kelas reguler, 4) Guru membantu siswa ABK jika ada kesulitan, 5) Guru menyusun kegiatan di kelas inklusi bersama guru pendamping. Pelaksanaan proses pembelajaran siswa $\mathrm{ABK}$ dan siswa reguler belajar bersama dalam ruang kelas, hanya pada waktu yang sudah dijadwalkan yaitu pada hari Jumat dan Sabtu siswa ABK dibawa ke luar kelas menuju ke kelas inklusi. Pada saat pelaksanaan proses pembelajaran guru kelas melakukan komunikasi dengan guru pendamping untuk menindaklanjuti hasil belajar di kelas reguler. Di kelas inklusi siswa ABK selama dua hari didampingi guru pendamping dan guru kelas untuk mendapatkan bantuan belajar. Di kelas inklusi guru menekankan kemampuan siswa ABK tidak hanya kognitif saja, tetapi kemampuan ketrampilan dan psikomotor juga dikembangkan.

Pendampingan kepada siswa ABK dengan cara guru kelas melakukan pendampingan belajar di kelas lebih intensif, dengan mengatur tempat duduk di sebelah guru. Siswa ABK juga mendapat pendampingan dari GPK di kelas inklusi. Siswa ABK mendapat bantuan pada kemampuan kognitif, ketrampilan, dan psikomotor. Pendampingan pada pertemuan pertama setiap kegiatan yang dilakukan di kelas, siswa ABK mendapat bantuan dari guru kelas. Guru mendesain kelas yang menyenangkan untuk belajar. Dalam proses pembelajaran ini GPK berada di dalam kelas untuk mendampingi guru kelas dalam proses pembelajaran. Siswa ABK mendapatkan pendampingan secara khusus untuk menguasai materi. Pada saat ini jika waktu habis siswa belum paham maka akan dipahamkan di kelas inklusi.

Pada pertemuan kedua guru pendamping memberi motivasi belajar, dan menasehati siswa supaya mengikuti pelajaran dengan baik. Guru menanyakan tentang materi-materi yang belum dipahami. Beberapa siswa memahami informasi dari guru sehingga ada komunikasi yang baik tentang materi yang belum dipahami. Tetapi ada beberapa siswa ABK yang mengalami kesulitan menyampaikan informasi diantaranya seperti siswa autis dan tuna grahita. Guru pendamping sudah sangat memahami kemampuan dan kharakterikstik masing-masing siswa ABK, 
sehingga tidak ada kesulitan dalam memahamkan. Di kelas inklusi ini siswa diberi kebebasan membuat deskripsi tentang benda. Sebagai contoh guru membawa sebuah kota kosong kemudian siswa diminta mendeskripsikan nama dan fungsi benda. Bagi siswa yang belum bisa menulis cukup melakukan pengamatan kemudian menceritakan deskripsi secara lisan. Siswa diminta membacakan/menceritakan deskripsinya. Guru beserta siswa lainnya memberikan penilaian deskripsi yang terbaik. Jadwal proses pembelajaran di kelas inklusi berlangsung sama dengan jadwal yang lainnya. Jadwal kegiatan hari Jumat digunakan untuk mendalami materi yang belum dikuasai, hari Sabtu digunakan untuk mengembangkan ketrampilan dan psikomotor. Proses pembelajaran di kelas inklusi berlangsung sangat familiar dan sangat mengakomodasi kemampuan siswa ABK. Siswa ABK sangat senang dan antusias belajar di kelas inklusi karena mereka bisa bereksplorasi sesuai keinginan dan kemampuannya tetapi tetap pada proses pembelajaran. Fungsi dari kelas inklusi adalah sebagai kelas untuk memberikan bantuan kepada siswa ABK untuk mendalami materimateri yang belum dipahami di dalam kelas dan juga untuk melayani kemampuan positif siswa yang bisa dikembangkan potensinya. Di kelas inklusi siswa $\mathrm{ABK}$ belajar tentang banyak hal baik kognitif, ketrampilan, maupun psikomotornya.

Ketika proses pembelajaran berlangsung di kelas reguler maupun di kelas inklusi dilakukan pengamatan secara cermat. Melalui pengamatan dalam pembelajaran akan diketahui sejauh mana model Pull Out bisa dilaksanakan dan berhasil. Pengamatan dilakukan sebelum pembelajaran, selama pembelajaran, dan sesudah pembelajaran. Pengamatan sebelum pembelajaran diperlukan untuk menyiapkan RPP bagi guru dan kesiapan dalam proses pembelajaran. Pada pengamatan sebelum pembelajaran guru menyiapkan semua perangkat pembelajaran. Pengamatan sesudah pembelajaran juga dilakukan untuk menindaklanjuti hasil pembelajaran. Setelah proses pembelajaran berlangsung maka kepala sekolah menyampaikan hasil kegiatan yang sudah dilaksanakan di kelas oleh guru dan siswa. Semua kegiatan guru dan siswa dicatat. Melalui pengamatan instrumen yang harus diisi yaitu instrumen untuk guru dan siswa. Hasil pengamatan akan menjadi data yang akan dianalisis.

Berdasarkan data diperoleh pengelolaan kelas oleh guru kelas pada siklus II $90 \%$ artinya ada 11 guru kelas pengelolaan kelasnya sangat baik untuk siswa ABK dan siswa reguler, dan hanya $10 \%$ guru atau 1 guru belum siap. Kemampuan kognitif siswa ABK sebesar $86 \%$ artinya sebanyak 22 dari 26 siswa ABK mempunyai kemampuan kognitif baik. Ada peningkatan kemampuan kognitif $24 \%$ dibanding siklus I sebesar $62 \%$. Hasil analisis data untuk kemampuan ketrampilan $81 \%$ artinya ada 21 siswa ABK mempunyai ketrampilan baik ini ada peningkatan $17 \%$ dibanding siklus I sebesar $64 \%$. Kemampuan psikomotor $84 \%$ artinya ada 21 dari 26 siswa ABK mempunyai kemampuan psikomotor baik, ada peningkatan sebesar $17 \%$ dari sebelumnya $67 \%$.

\section{Data kemampuan siswa ABK siklus II}

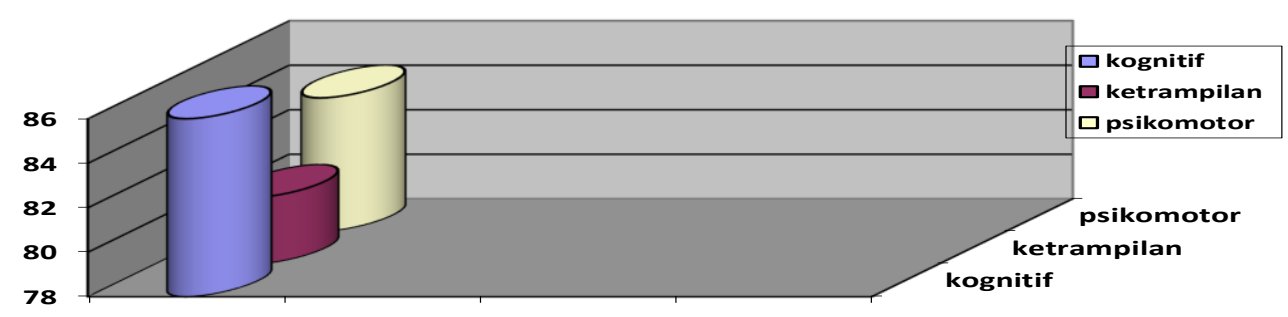


Berdasarkan diagram di atas bahwa kemampuan siswa ABK pada siklus II mengalami peningkatan. Kemampuan kognitif $86 \%$, ketrampilan $81 \%$ dan psikomotor $84 \%$. Berdasarkan data siklus II maka penelitian sudah berhasil karena sudah mencapai di atas $76 \%$. Ini berarti tidak diperlukan tindak lanjut karena pada

\section{Perbandingan Hasil Penelitian Siklus I dan Siklus II}

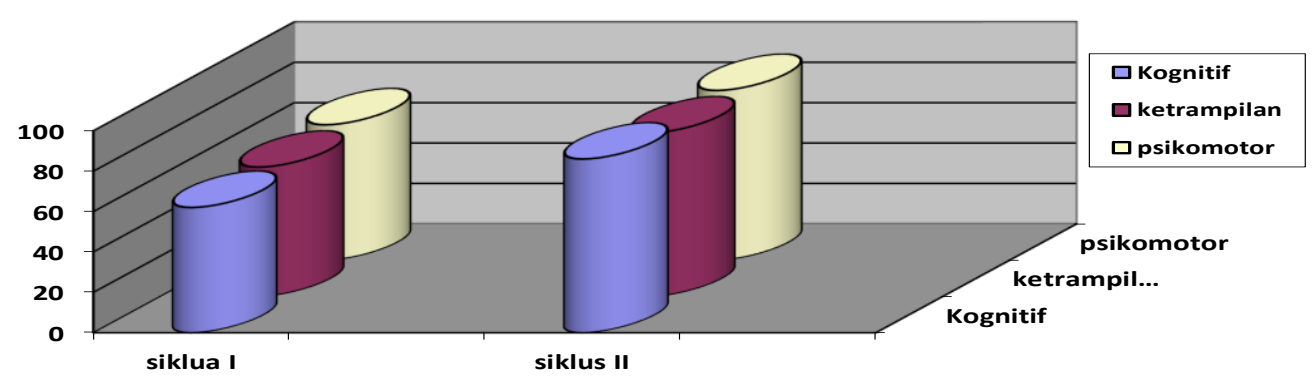

\section{Simpulan}

Data yang diperoleh dalam penelitian dapat disimpulkan bahwa model Pull Out dapat meningkatkan minat belajar anak berkebutuhan khusus di kelas reguler. Hal ini dibuktikan dengan hasil analisis yang mendalam dalam penelitian dan diperoleh data peningkatan yang signifikan pada siklus I dan siklua II. Guru menerapkan model Pull Out bagi siswa ABK dalam proses pembelajaran di kelas reguler melalui perencanaaan dan pengelolaan kelas yang maksimal.

1. Guru menerapkan model Pull Out bagi siswa ABK dalam proses pembelajaran di kelas reguler melalui perencanaaan dan pengelolaan kelas yang maksimal. Hal ini dapat dibuktikan keberhasilannya pada pengelolaan kelas oleh guru kelas pada siklus I yang hanya mencapai $33 \%$ kesiapannya, tetapi pada siklus II melalui perencanaan yang maksimal dapat meningkat menjadi 90 $\%$.

2. Model Pull Out dapat meningkatnya kemampuan kognitif siswa ABK. Keberhasilan meningkatkan kemampuan kognitif siklus I $62 \%$, siklus II menjadi $86 \%$ sehingga ada peningkatan $14 \%$. siklus II penelitian sudah berhasil. Hasil evaluasi penelitian dalam meningkatkan minat belajar siswa $\mathrm{ABK}$ pada siklus II sudah berhasil karena sudah mencapai indikator minimal $76 \%$. Bahwa model Pull Out mampu meningkatkan minat belajar siswa ABK di SD N Giwangan dengan melalui perencanaan yang baik di kelas inklusi. 
efisien dalam memberikan layanan yang sama antara siswa $\mathrm{ABK}$ dan siswa reguler.

\section{DAFTAR PUSTAKA}

Bandi Delphie. (2009). Psikologi Perkembangan (Anak Berkebutuhan Khusus). Klaten : PT Intan Sejati

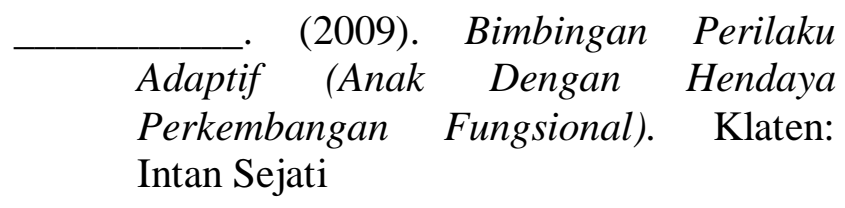

Bell Gredler, Margaret, E. (1994). Belajar dan Membelajarkan. Jakarta: Raja Grafindo

Dimyati. (1994). Belajar dan Pembelajaran. Yogyakarta: Reneka Cipta

Dimyati. (2008). Humanisasi Pendidikan. Yogyakarta: Bumi Aksara

Direktorat PLB. (2010). Mengelola kelas Inklusif dengan Pembelajaran yang Ramah. Jakarta: Direktorat PLB

Gavin Ingham. (2009). Memotivasi Orang. Jakarta : Erlangga

Mudjito., dkk.(2012). Pendidikan Inklusif. Jakarta : Baduose Media
Mudjiyanto, dkk. (2013). Modul Pelatihan Pendidikan Inklusif. Jakarta: Kemendikbud.

Munif Chotib. (2009). Sekolahnya Manusia. Bandung: Mizan Pustaka

Moeslichatoen. (2004). Metode Pengajaran. Jakarta : Rineka Cipta

Moleong.(2009).Metodologi Penelitian Kualitatif. Bandung: Rosdakarya.

Slameto. (2003). Belajar dan Faktor-faktor yang Mempengaruhinya. Jakarta: Rineka Cipta

Suharsimi. (2008). Penelitian Tindakan Kelas. Jakarta : Bumi Aksara

UNESCO. (2006). Tulkit LIRP- Merangkul Perbedaan : Perangkat untuk Mengembangkan Lingkungan Inklusif Ramah terhadap Pembelajaran. Indonesia: IDPN Indonesia

UNESCO. (2007). Tulkit LIRP- Merangkul Perbedaan: Perangkat untuk Mengembangkan Lingkungan Inklusif Ramah terhadap Pembelajaran. Indonesia: IDPN Indonesia 